O. O. Lapshyn, Dr. Sc. (Tech.), Assoc. Prof., orcid.org/0000-0001-8844-6354,

V.A. Shapovalov, Cand. Sc. (Tech.), Assoc. Prof., orcid.org/0000-0002-5965-2869,

M.V. Khudyk, Cand. Sc. (Tech.), orcid.org/0000-0002-1155-2535,

O. L. Shepel, Cand. Sc. (Tech.),

orcid.org/0000-0003-4581-5441
State Higher Educational Institution "Kryvyi Rih National University”, Kryvyi Rih, Ukraine, e-mail: ajax2805@gmail.com

\title{
INDUSTRIAL RESEARCH ON DUST TRAPPING EFFICIENCY BY THE FIBER FILTER IN ASPIRATION SHELTERS OF RELOADING UNITS
}

Purpose. Upgrading the efficiency of dedusting at workplaces of the iron ore crushing and sorting plants by means of a fiber filter in aspiration shelters, reducing dust deposits in aspiration pipelines and load on filters of aspiration installations.

Methodology. Monitoring of the dustiness level in the working area of the crushing and sorting plant and determination of the dust trapping efficiency through a fiber filter were carried out on the base of the standardized technique methodical instructions 4436-87 "Dust gravimetric determination in the work area and in ventilation systems". For this purpose, a dust trapping device consisting of a filter holder (allonge), a set of AFA filters from a hydrophobic material of the FPP grade, an aspirator and a flow meter was used.

Findings. Relatively high efficiency of dust trapping (coarse dust trapping in particular) with a fiber filter for aspiration shelters of iron ore reloading units at the crushing and sorting plant was confirmed. A fiber filter enables to reduce the dustiness of working zone air for machinists of the technological equipment by almost $45 \%$.

Originality. The laboratory-made dependence of the iron ore dust trapping efficiency of a fiber filter of the nylon and polyvinylchloride double curtains with different surface charges in the aspiration shelters of the reloading units on the distance between the curtains in the filter was demonstrated. Completed research shows the dust trapping efficiency of a fiber filter made of double nylon and polyvinylchloride curtains installed alternately at least 6 pcs in number.

Practical value. The design of the fiber filter for aspiration shelters was improved, whose use enables to catch iron ore dust directly in a shelter and reduce its settling in the aspiration air duct system. A technique for calculating the parameters of fiber filters for aspiration shelters of different constructions has been developed.

Keywords: fiber filter, dust deposits, aspiration shelter, dust trapping

Introduction. PJSC Kryvyi Rih iron-ore combine is the major iron ore mining company that annually produces more than 6 million tons of iron ore. It includes the mines Rodina, Oktiabrska, Hvardiiska and Ternivs$\mathrm{ka}$. The Rodina mine with a design capacity of $2.5 \mathrm{mi}-$ llion tons per year produces martite ores represented by martitic and gyotite-martiteite quartzites.

A variety of technological crushing-and-screening and transporting equipment is used in the processing of martitic iron ore at the Crushing and Sorting Plant of the Rodina mine PJSC Kryvyi Rih iron-ore combine. Cone mills of the particular type are used for coarse, medium and fine milling. Preliminary classification is carried out on the grate screens, and the following distribution of iron ore by size is performed on vibrating or inertial screens.

Iron ore is transported through inclined and vertical chutes, vibrating or plate feeders, as well as belt conveyors. Grinding, sorting and transportation of iron ore results in iron ore dust emissions into the production facilities, which can lead to occupational diseases like chronic dust bronchitis, silicosis and an increase in the

(C) Lapshyn O. O., Shapovalov V.A., Khudyk M.V., Shepel O. L., 2018 morbidity, since dust can carry respiratory pathogens.

The experience of the Kryvbas mining enterprises shows that the intensity of dust generation during iron ore transshipment depends on many factors like physical properties of the material: size, humidity, temperature, geometric parameters of the reloading unit, and others, and can reach up to $15-20$ grams per second or more. However, regardless of the intensity of the dust emission, the reloading units are equipped with aspiration shelters. By sucking air out, a stable dilution should be supported up to $12 \mathrm{~Pa}$ [1], which is associated with significant capital and operating costs.

According to the research results, it was found that the actual dustiness at workplaces for machinists of conveyors, feeders, screeners, crushers in the CSP Rodina mine exceeds the maximum permissible concentration by $1.5-3$ times.

Analysis of the recent research and publications. The issue on dust trapping in the processing of iron ore raw materials is referred to in works of prominent scientists, such as I. M. Logachev, O. D. Neikov, V.V. Nedin, V. O. Minko, A. Yu. Waldberg, V. N. Uzhov, I. I. Afanasiev, A. V.Sheleketin, O. Ye. Lapshyn, O. V. Kalmykov, K. G. Rudenko, F. I. Danchenko, V.S. Vashchenko, 
K. G. Rudenko, O. M. Golyshev, V. I. Muliavko, A. M. Kirichenko, A. A. Nemchenko, and others.

In order to meet environmental and sanitary requirements of various standards and norms (TRGS 900, BGI 5047, EN ISO 14001: 2004, and so forth), at enterprises of the European Union and the United States of America, for trapping industrial dust in the places of its emission there can be used water mists or electrically charged mists (BSW, Kiel, Lech-Stahlwerke (LSW), Mettingen, Germany, and others), cyclones (Corus, Eimeiden, Netherlands, etc.), sleeve filters (ArcelorMittal, Fossur-Mer, France, Thyssen Krupp Stahl, Duisburg, Germany, Inland Steel, Chicago, USA, and others) [2] and electrostatic filters (ArcelorMittal, Ghent, Belgium, Inland Steel, Chicago, USA, Thyssen Krupp Stahl, Duisburg, Germany, and others) [3].

At industrial enterprises of Ukraine, the aspiration systems are being widely applied for intensive dust removal. The prerequisite of an effective localization of dust emissions by the aspiration systems is to imply the aspiration shelters equipped with ventilation units at places of dust emission and subsequent purification of the filters.

To date, there are two main ways to reduce dust release into the aspiration system when reloading bulk materials [4]:

1) reduction of air volume, which is sucked off from the aspiration shelter;

2) reduction of dust content in the air, which is sucked off from the aspiration shelter.

Reducing the dust ejection of aspiration air can be achieved in two ways: to reduce the volumes of air ejected into the lower shelter, as well as volumes of air sucked in through the leaks.

The main research activities to reduce the volume of dust ejection are the following [5]:

1. Increase in the aerodynamic resistance of the transshipment chute by installing the valves and gate equipment from the material reloaded.

2. Organization of closed air circulation (natural, forced by ejection of water drops, aspiration fan and combined) in the aspiration shelter.

The essential part of the total amount of air sucked off from the shelters is the volume of air absorbed through leaks and openings of aspiration shelters.

Two main ways to reduce the air absorbed through leaks are: development of means, which allow reducing the necessary dilutions in the shelters by controlling the ejection jet, and increasing the tightness of the shelters by improving the aerodynamic characteristics of seals [6].

Unsolved aspect of the problem. The issue of costeffectiveness of aspiration systems, improvement of employment conditions, as well as dust deposit prevention in aspiration pipelines by up-to-date means of dedusting in the aspiration shelters is still relevant and has yet to be fully implemented. For individual sections of aspiration systems (horizontal and gently sloping sections of pipelines, bends, transitions, and others), the dust filling of the cross-section can reach 85-90\% [7]. Failure to take action could result in a disruption of the aerodynamic characteristics of the system, an increase in the load on the ventilation equipment, in some cases, air duct breaks and falls on equipment or people.

Conveyor reloading units comprise the biggest group of dust sources at mining enterprises. Taking into account the vast volumes of iron ore raw materials processed, the total power of the dust emission from these units may be high enough. In this regard, new constructive suggestions for improving dust catching in aspiration shelters relate to the reloading units of bulk materials.

Objectives of the article. Industrial research was conducted in order to increase the dust trapping efficiency at workplace of iron ore crushing plants by means of dust trapping fiber filters in aspiration shelters, to reduce dust deposits in aspiration pipelines, as well as load on filters of aspiration installations.

Presentation of the main research. Operating experience of aspiration systems at the Kryvbas mining enterprises shows that ejection of dust into the aspiration system is reduced, when sucking the air from aspiration shelters. However, the specific dust content in aspiration air remains high and does not eliminate dust deposits in aspiration pipelines, violating the aerodynamic stability of the aspiration system.

The ability of trapped dust to return directly to the process is the advantage of the shelters and local dustremoving devices for dry dust collection (dust collectors or filtering and ventilating units).

Gravitational, inertial, electric, magnetic forces, as well as preliminary coagulation of dust particles are most cost-effective for these purposes. Coagulated dust particles can be caught in simple devices with a small aerodynamic resistance, as well as in shelters through gravitational forces. Air dedusting technology in the filters of the final purification, thus, becomes simple and economically efficient because of reducing the initial dust concentration. Preliminary dust deposition in the aspiration shelters of the Kryvbas mining enterprises makes up to $63 \%$ of the coarse dust and $37 \%$ of fine dust. Reduction of the initial dust concentration facilitates and reduces the cost of air dedusting technology in filters of the final purification. Apart from that, precleaning in shelters improves the operation reliability of aspiration air ducts, prevents from the dust deposition in them and reduces the abrasive wear of the duct walls, hence, increases the efficiency of aspiration systems in general.

Aspiration shelters of rock reloading units equipped with a fiber filter make one of priorities aimed at preventing dust emissions into the environment, reducing the intensity of dust emission or dust material with aspiration air. For this design, the patent of Ukraine No. 52371 on the utility model was issued.

Under laboratory conditions, the dependence of the decrease in the dust emission intensity on average to $27 \%$ was established due to the filter with the doublefiber curtains in the receiving bunker (shelter). In the study of the design and operating parameters (packing density of fibers in the double-curtain filters, the distance between the double curtains and their number in the filter, the dusty air throughput) of a six-row fiber filter, the iron-dust trapping efficiency reached $95-97 \%$. 
Dust trapping by double-fiber filter curtains consists in depositing dust particles on the fibers due to contact, inertial collision, Brownian motion, as well as action of gravitational and electrostatic forces.

Dust particles settle down on a pure fiber due to the adhesion of dust particles to the surface of the fibers. As the dust particles accumulate, the curtains fibers are covered with these particles resulting in subsequent deposition on a layer of particles settled earlier. The increase in dust deposits on fibers makes a structural change in the filter medium due to the autoheziation forces. As a result of this reaction, branched aggregates are formed that become an auxiliary filtration medium. A secondary filtering layer inside the fiber curtain goes along with significantly raising the efficiency of dust trapping and increasing the hydraulic resistance.

Synthetic fibers and dust particles can carry electrical charges. In this case, electrical interaction has a sufficient operating range so that the dust particles move toward the fibers and come into contact with their surfaces. Electric forces are common practice to increase the dust trapping efficiency. Charging of particles and fibers can occur by friction between particles during collision and by friction of the dust particles against the surface of an aspiration shelter or a reloading chute. The charge polarity depends on the chemical composition and conditions of the dust formation. The dust generated from the grinding process contains positively and negatively charged particles.

The authors found that dust from iron ore extracted and processed in the Kryvbas contains $54.4 \%$ of positively charged particles, $36.6 \%$ of negatively charged particles and $9 \%$ of neutral particles.

Electrostatic interaction contributes to the aggregation of particles and formation of branched aggregates on the filter fibers. Coagulated dust particles are better trapped by curtains, while aggregates formed on fibers provide effective dust particles trapping.

Industrial research on the effectiveness of dust control by a fiber filter in aspiration shelters of reloading units were carried out at the Crushing and Sorting Plant of the Rodina mine PJSC Kryvyi Rih iron-ore combine, the result of which was approved by the act.

The efficiency of dust trapping with a fiber filter was determined by measuring the air dustiness in the aspiration air duct. The dusty air is ejected from the reloading unit, before and after filtration by the fiber filter according to the method instructions 4436-87 "Dust gravimetric determination in the work area and in ventilation systems".

Results of industrial research on a fiber filter conducted at the Crushing and Sorting Plant of the Rodina mine PJSC Kryvyi Rih iron-ore combine are shown in Tables 1 and 2.

Experimental results (Table 1) indicate that the poor sealing of the aspiration shelter and high air speed in a filter $(0.45 \mathrm{~m} / \mathrm{s})$ did not lead to the optimal level 95-97\% of air dedusting in laboratory conditions.

As can be seen from Table 2, large fractions from 250 to $50 \mu \mathrm{m}$ predominate in the dust trapped by a fiber filter, that makes up to $93 \%$ of the total amount of
Table 1

Results of experimental operation of the fiber filter in aspiration shelter of the reloading unit at the Crushing and Sorting Plant of the Rodina mine PJSC Kryvyi Rih iron-ore combine

\begin{tabular}{|c|c|c|c|c|}
\hline \multirow[b]{2}{*}{ 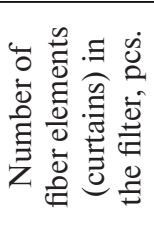 } & \multirow[b]{2}{*}{ 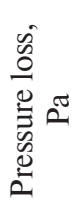 } & \multicolumn{2}{|c|}{ Air dust level, mg $/ \mathrm{m}^{3}$} & \multirow[b]{2}{*}{ 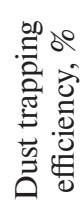 } \\
\hline & & 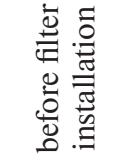 & 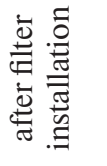 & \\
\hline 1 & 14.5 & 740 & 628 & 15.1 \\
\hline 2 & 28.0 & 812 & 687 & 15.4 \\
\hline 3 & 41.5 & 771 & 614 & 20.3 \\
\hline 4 & 57.0 & 610 & 425 & 30.4 \\
\hline 5 & 71.5 & 673 & 368 & 45.3 \\
\hline 6 & 86.0 & 685 & 339 & 50.5 \\
\hline
\end{tabular}

Table 2

Granulometric composition of dust trapped by a fiber filter in aspiration shelters of the reloading units

\begin{tabular}{|c|c|c|c|c|c|c|}
\hline 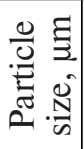 & $<50$ & $50-63$ & $63-100$ & $100-160$ & $160-250$ & $\Sigma$ \\
\hline$\%$ & 6.95 & 12.42 & 23.39 & 25.92 & 31.32 & 100 \\
\hline
\end{tabular}

dust trapped. Dust trapping of the fraction $<50 \mu \mathrm{m}$ is $6.95 \%$.

Despite the relatively low efficiency of the fiber filter in industrial conditions of the Crushing and Sorting Plant of the Rodina mine PJSC Kryvyi Rih iron-ore combine, it should be noted that the air dustiness in the reloading unit has decreased by approximately $45 \%$ (from 6.1 to $3.4 \mathrm{mg} / \mathrm{m}^{3}$ ).

However, industrial research allowed confirming the dependence of the iron ore dust trapping efficiency in the aspiration shelters of reloading units equipped with a double-row fiber filter from nylon and polyvinylchloride double curtains with different surface charges on the distance between the curtains in the filter

$$
E=\frac{-585.3+589.4 \cdot 10^{3} \cdot L}{1+8.4 \cdot 10^{3} \cdot L+930 \cdot L^{2}},
$$

where $L$ is the distance between double-fiber curtains in a filter, $m$.

When intercontacting the curtain fibers, the double curtains in the fiber filter lose their electrostatic charge. As a result, the electrostatic mechanism of dust trapping is weakened and deposition on the fibers occurs mainly due to inertial and gravitational forces.

In order to avoid contact of the double fiber curtains with one another, the following condition should be followed

$$
L \geq b+2 h_{f}+2 \operatorname{tg} \gamma_{\text {ext. }}\left(a+l_{c}\right),
$$


where $b, a$ are width and height of the profile for fibres fastening in double curtains, $\mathrm{m} ; h_{f}$ is the thickness of the fiber layer, $\mathrm{m} ; l_{c}$ is the length of the double curtain filter, $\mathrm{m}$; $\gamma_{\text {ext. }}$ is the angle of external ripping of fibers in the double curtains of the fiber filter (for double curtains of a new filter $\gamma_{\text {ext. }}=3^{\circ}$; for double curtains of a filter after regeneration $\gamma_{\text {ext. }}=6^{\circ}$ ), degree.

After advancing the fiber filter design (installated spring shock absorbers to minimize the effect of technological vibration, as well as fixtures for vibration equipment), the patent of Ukraine No. 78881 on the utility model was received [8]. After that, industrial research on dust trapping efficiency was extended at the Medium and Fine Cushing Plant and at JSC-1 Concentrating Poltava Mining Enterprise, whose filtration efficiency was reached 92-93\% (Tables 3, 4).

Based on the results of industrial research, the methodology for calculating the design and technological parameters of a six-raw fiber filter in the aspiration shelter

Table 3

Results of experimental operation of the fiber filter in aspiration shelter of the reloading unit at the Medium and Fine Cushing Plant of JSC Poltava Mining Enterprise

\begin{tabular}{|c|c|c|c|c|}
\hline \multirow[b]{2}{*}{ 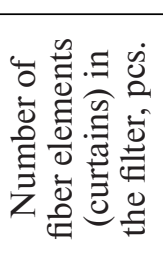 } & \multirow[b]{2}{*}{$\begin{array}{l}\tilde{0} \\
0 \\
0 \\
0 \\
\vdots \\
0 \\
0 \\
0 \\
0 \\
0\end{array}$} & \multicolumn{2}{|c|}{ Air dust level, $\mathrm{mg} / \mathrm{m}^{3}$} & \multirow[b]{2}{*}{ 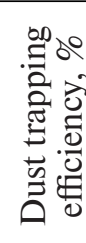 } \\
\hline & & 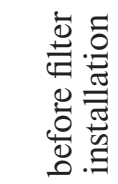 & 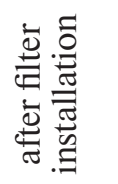 & \\
\hline 1 & 19.8 & 842 & 625 & 25.8 \\
\hline 2 & 29.7 & 832 & 295 & 64.6 \\
\hline 3 & 40.0 & 763 & 176 & 77.0 \\
\hline 4 & 51.1 & 710 & 117 & 83.5 \\
\hline 5 & 61.5 & 673 & 60 & 91.1 \\
\hline 6 & 70.3 & 797 & 59 & 92.6 \\
\hline
\end{tabular}

Table 4

Results of experimental operation of the fiber filter in aspiration shelter of the reloading unit at JSC-1

Concentrating Poltava Mining Enterprise

\begin{tabular}{|c|c|c|c|c|}
\hline \multirow[b]{2}{*}{ 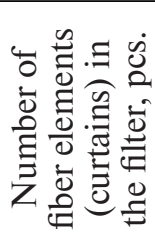 } & \multirow[b]{2}{*}{$\begin{array}{l}\hat{0} \\
0 \\
0 \\
0 \\
\vdots \\
0 \\
0 \\
0 \\
0\end{array}$} & \multicolumn{2}{|c|}{ Air dust level, $\mathrm{mg} / \mathrm{m}^{3}$} & \multirow[b]{2}{*}{ 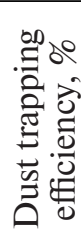 } \\
\hline & & 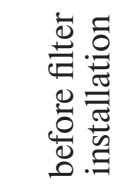 & 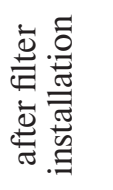 & \\
\hline 1 & 20.1 & 712 & 526 & 26.1 \\
\hline 2 & 30.5 & 794 & 287 & 63.9 \\
\hline 3 & 41.2 & 774 & 163 & 78.9 \\
\hline 4 & 50.8 & 746 & 111 & 85.1 \\
\hline 5 & 62.0 & 813 & 77 & 90.5 \\
\hline 6 & 71.1 & 805 & 56 & 93.0 \\
\hline
\end{tabular}

of the reloading unit was developed and implemented on the example of aspiration shelters developed by the Research Institute for Occupational Safety and Ecology in the Mining and Metallurgical Industry of Kryvyi Rih National University. The algorithm consists in the following:

1. According to known standardized techniques developed by the Research Institute for Occupational Safety and Ecology in the Mining and Metallurgical Industry, the amount of air sucked out from the aspirational shelter is calculated. $Q_{a}, \mathrm{~m}^{3} / \mathrm{h}$.

2. The total filtering surface of the fiber filter is determined

$$
S_{\text {total }}=\frac{Q_{a}}{3600 v}
$$

where $v=0.33 \mathrm{~m} / \mathrm{s}$ is the recommended dusty air speed through the filter in the shelter.

3. It is assumed that a fiber filter of six dual fiber curtains (elements) with the alternating charges of the fiber is installed in the aspiration shelter.

4. The height of the box with the removable filter frame (the width of the box is equal to the width of the shelter) is calculated

$$
H_{S . B .}=\frac{S_{\text {total }}}{B_{s h}}-H_{s h},
$$

where $B_{s h}, H_{s h}$ are the width and the height of the aspiration shelter, $\mathrm{m}$.

5. The double curtains for the filter are made of fibers of nylon and polyvinyl chloride with a diameter of $5 \mu \mathrm{m}$. For their fixing, a square or rectangular profile preferably of aluminum or copper is used in order to restore the electrostatic charge on the curtains.

6. The thickness of the fiber layer in the double curtains of the filter at given density of packing $(\alpha)$ is determined by the formulas:

a) if $\alpha$ is given in proportions of a unit

$$
h_{f}=\frac{b+\operatorname{tg} \gamma_{e x t .}\left(2 a+l_{c}\right)}{\alpha^{-1}-2}
$$

b) if $\alpha$ is given in pcs. $/ \mathrm{m}^{3}$

$$
h_{f}=\frac{\pi d_{f}^{2} l_{c}\left(b+\operatorname{tg} \gamma_{\text {ext. }}\left(2 a+l_{c}\right)\right)}{4 \alpha^{-1}-2 \pi d_{f}^{2} l_{c}},
$$

where $d_{f}$ is the fibre diameter, $\mathrm{m}$.

7. The required distance between the double curtains in the filter from equation (1) can be obtained.

8. The pressure losses as the air passes through the fiber filter by the following formula is calculated

$$
\Delta P_{z}=\frac{v^{2} \rho}{2} \zeta
$$

where $\rho$ is the air density, $\mathrm{kg} / \mathrm{m}^{3} ; \zeta=1071$ is the coefficient of local resistance of a six-raw fiber filter.

The laboratory and industrial research demonstrated that a filter with double curtains can accumulate (to full saturation) up to $6.5 \mathrm{~kg} / \mathrm{m}^{2}$ of dust, which corresponds 
to $155 \mathrm{~kg}$ of dust trapped along the length of 6 curtains with a filter area of $24 \mathrm{~m}^{2}$. If the maximum air dust level in the aspiration shelter is $1 \mathrm{~g} / \mathrm{m}^{3}$ and at a dusty air aspiration volume of $5000 \mathrm{~m}^{3} / \mathrm{h}$, the capacity of the fiber filter ensures the continuous dust accumulation during 30 hours of operation. Thus, the periodicity of the replacement of the filter is once a day in the inter-shift period.

Regeneration of the fiber filter can be done in two ways:

1. Regeneration involves shaking equipment as a vibrator with an electric drive (for example, type EV-320) installed on the filter frame. When turned on periodically, the vibrator shakes a settled dust of the filter onto the rock moving along the conveyor. The frequency of vibration is determined from the area of the curtains and the intensity of dust accumulation on them. This method is suitable if there are no other reloading units along the tract, since large dust emissions are possible as a result of dust accumulation in the mountainous mass.

2. If the vibration equipment is not installed on the fiber filter frame, the removable frame of the fiber filter with dusty double curtains is replaced by a similar pure fiber filter through the cover of the suction box by the lifting mechanism. Or after regeneration in a special bunker, by means of vibration equipment and also by replacing the electrostatic charge on the fibers, the filter is returned to its place.

To be effective, aspiration shelters equipped with a fiber filter need constant monitoring and timely elimination of detected faults.

The effectiveness of dust trapping in aspiration shelters with a fiber filter reduces sharply when air in-takes at the bottom of the shelter. Therefore, it is advisable to perform shiftly visual and weekly detailed check of the end-plates and side-plates sealing of the shelter. At least once a month, the integrity of these plates should be verified. If necessary, their replacement should be appointed.

The visual check has a number of shortcomings (employee competence, employee health, and others) and does not allow detecting the existing defects in the aspiration shelter and others and assessing the effectiveness of dust trapping objectively. Therefore, it is recommended to perform a dust control survey every quarter, which makes it possible to establish the true condition of the aspiration system.

The worn fiber filter is to be replaced, when reduction of the dust trapping efficiency with constant aerodynamic parameters in the aspiration shelter is assessed through instrumental measuring.

Conclusions and recommendations for further research. Thus, the experimental operation of a fiber filter (for coarse dust trapping, in particular) has confirmed its potential for use in aspiration shelters of rock reloading units. The fiber filter of the reloading units allows reducing the dustiness of working zone air for machinists engaged in iron ore processing by approximately $45 \%$. The technique of the fiber filter selection for aspiration shelters was developed and implemented on the example of aspiration shelters developed by the Re- search Institute for Occupational Safety and Ecology in the Mining and Metallurgical Industry. The real study regarding the future of a fiber filter to capture other types of industrial dust including coal, granite, and others needs to be initiated.

\section{References.}

1. Logachev, I. N., Logachev, K. I. and Averkova, O. A., 2013. Energy saving in aspiration. Moscow: Regulyarnaya i haoticheskaya dinamika.

2. Remus, R., Aguado-Monsolet, M.A., Roudier, S. and Sancho, L.D., 2013. Best Available Techniques (BAT) Reference Document for Iron and Steel Production. Luxembourg: Publications Office of the European Union.

3. Andrew B. Cecala, Andrew D. O'Brien, Joseph Schall, Jay F. Colinet, William R. Fox, Robert J. Franta, Jerry Joy, Wm. Randolph Reed, Patrick W. Reeser, John R. Rounds and Mark J. Schultz, 2012. Dust Control Handbook for Industrial Mineral Mining and Processing. Pittsburgh [pdf]. Available at: <https://www. cdc.gov/niosh/mining/userfiles/works/pdfs/2012-112. pdf $>$ [Accessed 12 February 2017].

4. Goncharov, V.B., Khardikov, I.P. and Kharlamov, E. V., 2016. Analysis of shelters places of overload friable material. Nauchnyi almanakh, 15, pp. 411-414. 5. Saparova, G. K., Medeubaev, N.A., Amanzholov, Zh. K., Balabas, L. Kh. and Komleva, E. V., 2015. Methods for determination of volumes of the air ejected from shelters at the overload of mountain mass. Vestnik $V K G T U, 3$, pp. 23-27.

6. Popova, N.P. and Prigorodova, T. N., 2015. Problems of localization dust emissions from extended sources. Bezopasnost zhiznedeiatelnosti, 4, pp. 26-30.

7. Dengub, T. V. and Khudik, N. V., 2014. Research on aerodynamic drag aspirating air flues by dusty deposits. Metallurgicheskaia $i$ gornorudnaia promyshlennost, 4, pp. 115-117.

8. Dengub, V. I., Shapovalov, V.A. and Hudyk, N. V., 2015. Determination of fiber filter dust collecting efficiency depending on particles distribution of industrial dust. Metallurgical and Mining Industry, 5, pp. 67-71.

\section{Промислові дослідження ефективності вловлювання пилу волоконним фільтром в аспіраційних укриттях перевантажувальних вузлів}

\section{О. О. Лапшин, В.А. Шаповалов, М.В. Худик, О. Л. Шепель}

Державний вищий навчальний заклад „Криворізький національний університет“, м. Кривий Ріг, Україна, e-mail: ajax2805@gmail.com

Мета. Збільшення ефективності зниження вмісту пилу в повітрі робочих місць залізорудних дробильно-сортувальних фабрик за рахунок уловлювання пилу волоконним фільтром у корпусі аспіраційних укриттів, попередження відкладень пилу в аспіраційних повітропроводах і скорочення пило- 
вого навантаження на фільтри аспіраційно-витяжних систем.

Методика. Вимірювання запиленості повітря на робочих місцях працівників дробильно-сортувальної фабрики й визначання ефективності пиловловлювання волоконним фільтром здійснювалося гравіметричним методом встановлення концентрації пилу за стандартною методикою МУ 4436-87 „Гравіметричне визначання пилу в повітрі робочої зони і в системах вентиляційних установок“. При цьому використовувався пиловловлюючий пристрій, що складається 3 фільтротримача (аерозольного патрона), набору аналітичних фільтрів АФА-ВП із гідрофобного матеріалу марки ФПП-15, аспіратора й витратоміра.

Результати. Підтверджена у виробничих умовах дробильно-сортувальної фабрики достатньо велика ефективність (особливо за пилом крупних фракцій) пиловловлювання волоконним фільтром для аспіраційних укриттів вузлів перевантаження залізної руди. Обладнання вузлів перевантаження волоконним фільтром може сприяти зменшенню запиленості повітря робочої зони машиністів технологічного устаткування фабрики майже на $45 \%$.

Наукова новизна. Підтверджена отримана при проведенні експериментальних досліджень залежність ефективності вловлювання пилу в корпусі аспіраційних укриттів вузлів перевантаження залізорудної сировини, оснащених волоконним фільтром з подвійними завісами (із капрону й полівінілхлориду), що мають різний знак поверхневого трибозаряду, від відстані між завісами у фільтрі. Доведена ефективність пиловловлювання волоконного фільтру, зробленого з подвійних завіс, установлених послідовно з чергуванням заряду, у кількості 6 шт.

Практична значимість. Були виправлені конструктивні недоліки волоконного фільтра для аспіраційних укриттів, застосування якого дозволяє вловлювати залізорудний пил у корпусі укриття й зменшити ймовірність його відкладення в системі аспіраційних повітроводів. Розроблена методика визначання параметрів волоконного фільтру, яким можуть бути обладнані корпуси аспіраційних укриттів різної конструкції.

Ключові слова: волоконний фільтр, відкладення пилу, корпус аспіраційного укриття, вловлювання пилу

\section{Промышленные исследования эффективности улавливания пыли волоконным фильтром в аспирационных укрытиях перегрузочных узлов}

\author{
А. А. Лапшин, В. А. Шаповалов, Н. В. Худик, \\ А. Л. Шепель
}

Государственное высшее учебное заведение „Криворожский национальный университет“, г. Кривой Рог, Украина, e-mail: ajax2805@gmail.com
Цель. Повышение эффективности обеспыливания воздуха рабочих мест дробильно-сортировочных фабрик железной руды путем улавливания пыли волоконным фильтром в аспирационных укрытиях, уменьшение пылевых отложений в аспирационных трубопроводах и снижение нагрузки на фильтры аспирационно-тяговых устаноBOK.

Методика. Измерение запыленности воздуха рабочей зоны работников дробильно-сортировочной фабрики и определение эффективности улавливания пыли волоконным фильтром производилось гравиметрическим методом определения концентрации пыли по стандартизованной методике МУ 4436-87 „Гравиметрическое определение пыли в воздухе рабочей зоны и в системах вентиляционных установок“. Для этого применялось пылеулавливающее устройство, которое состоит из фильтродержателя (аллонжа), набора фильтров АФА из гидрофобного материала марки ФПП, аспиратора и расходомера.

Результаты. Подтверждена в промышленных условиях дробильно-сортировочной фабрики относительно высокая эффективность улавливания пыли волоконным фильтром для аспирационных укрытий перегрузочных узлов (особенно по крупнодисперсной пыли) железной руды. Использование волоконного фильтра на узлах перегрузки может способствовать снижению запыленности воздуха рабочей зоны машинистов технологического оборудования фабрики почти на $45 \%$.

Научная новизна. Подтверждена выявленная в лабораторных условиях зависимость эффективности улавливания железорудной пыли в аспирационных укрытиях перегрузочных узлов, оборудованных волоконным фильтром из капроновых и поливинилхлоридных двойных штор разного знака поверхностного заряда, от расстояния между шторами в фильтре. Показана эффективность улавливания пыли волоконным фильтром, изготовленным из двойных капроновых и полихлорвиниловых штор, установленных поочередно, в количестве не менее 6 шт.

Практическая значимость. Была усовершенствована конструкция волоконного фильтра для аспирационных укрытий, использование которого позволяет улавливать железорудную пыль непосредственно в укрытии и уменьшить ее оседание в системе воздуховодов. Разработана методика расчета параметров волоконных фильтров, которыми оборудуются аспирационные укрытия разных конструкций.

Ключевые слова: волоконный фильтр, отложения пыли, аспирационное укрытие, улавливание пыли

Рекомендовано до публікації докт. техн. наук А. О. Гуріним. Дата надходження рукопису 11.12.16. 